\title{
Postglacial dispersal, glacial refugia, and clonal structure in Russian/Siberian populations of the arctic Daphnia pulex complex
}

\author{
LAWRENCE J. WEIDER* \& ANDERS HOBAEK† \\ *Abteilung Ökophysiologie, Max-Planck-Institut für Limnologie, Postfach 165, D-24302 Plön, Germany and \\ $\uparrow$ Norwegian Institute for Water Research, Thormohlensgt. 55, N-5008, Bergen, Norway
}

\begin{abstract}
Results from an extensive allozymic survey of the genetic (clonal) structure of Russian/Siberian populations in the arctic Daphnia pulex complex yielded high clonal diversity/richness estimates, at both the intrapopulational and intraregional levels. Highest levels of clonal diversity were detected in the heart of the Beringian glacial refuge, with lower levels detected in glaciated regions (western Russia). mtDNA haplotype diversity (based on RFLPs) showed similar spatial trends, with the highest levels of haplotype diversity again being found in Beringia. Several haplotypes were extremely widespread (in the order of thousands of kilometres across the breadth of Eurasia), and evidence for presumed mutationally derived haplotypes was plentiful. Spatial autocorrelation analysis revealed a significant clinal pattern in the degree of genetic similarity among mtDNA haplotypes. In addition, similarity of clonal arrays (based on allozymes) showed a significant inverse association with geographical distance; i.e. similarity of clonal arrays between populations increased with decreasing geographical distance between populations. Sporadic sexual reproduction (based on Hardy-Weinberg expectations) was detected in Beringia, and has undoubtedly played a role in fuelling the production of novel genotypes. Our results suggest that vast expanses of northern Eurasia have been colonized by a small number of geographically widespread haplotypes, with more regionally restricted haplotypes constituting the remaining lineages. We discuss our results with in the general framework of biogeographical colonization events of the Arctic by members of the $D$. pulex complex, and place these data into the broader picture of the importance of Beringia as a glacial refuge for many taxa during the Pleistocene.
\end{abstract}

Keywords: allozymes, Beringia, Daphnia, glacial refugia, mtDNA, phylogeography.

\section{Introduction}

The biogeographical structuring of much of the Holarctic fauna and flora has been greatly influenced by the repeated episodes of glaciation and deglaciation during the Pleistocene, which have caused numerous range expansions, contractions. and fragmentations of virtually all taxa across the Holarctic (Pielou, 1979). Changes in the distribution of a given species have undoubtedly influenced the population dynamics and underlying genetic structure of these organisms (Avise, 1994). With the increased use of molecular techniques to assess levels of genetic differentiation among populations,

*Correspondence. E-mail: wei@mpil-ploen.mpg.de and the concomitant development of the field of phylogeography (Avise, 1994), we are seeing increasing evidence of the impact that the Pleistocene glaciations/deglaciations have played in the present phylogenetic and phylogeographical associations of arctic flora and fauna (Bernatchez \& Dodson, 1994; Abbott et al., 1995).

One region of the Holarctic, which has been implicated as serving a pivotal role in the recolonization of vast expanses of both the Eurasian and North American Arctic, is Beringia (Hopkins et al., 1982). Palaeoecological evidence indicates that Beringia (vast areas of eastern Siberia stretching into north-western North America, primarily Alaska) has served as the most important Pleistocene glacial refuge, and the source for multiple 
colonizations/recolonizations of glaciated regions in the Arctic.

Recent work has focused on the phylogeographical reconstruction of a variety of arctic organisms, in particular members of the Daphnia pulex (Crustacea; Anomopoda) species complex (Weider \& Hobæk, 1994; Weider et al., 1996). This small passively dispersed primarily freshwater organism has a circumarctic distribution (Haney \& Buchanan, 1987). Its primarily clonal mode of reproduction allows one to examine levels of clonal richness/diversity at a variety of spatial scales.

Briefly, most arctic Daphnia populations in this complex reproduce via obligate parthenogenesis. Both direct-developing (subitaneous) and diapausing eggs (encased in a resistant structure called an ephippium) are produced apomictically, with resulting offspring being genetic replicates of their mothers. Ephippia are passively dispersed between habitats, and serve as both the dispersal and diapausing stage of the life cycle. The sporadic production of males (Tash, 1971; Haney \& Buchanan, 1987; L. Weider, P. D. N. Hebert \& A. Hobæk, personal observations), which are genetic replicates of their mothers, does not exclude the possibility of occasional sexual reproduction. To date, sexual reproduction among arctic Daphnia has not been viewed as playing a very important present-day role in influencing the population genetic (clonal) structure in these populations (Weider et al., 1987). For the vast majority of arctic populations in the $D$. pulex complex that have been studied, obligate parthenogenesis is the sole reproductive mode.
Our study examined the population genetic (clonal) structure of members of this species complex across the northern fringe of Russia/ Siberia, and compared (using both allozymes and mitochondrial DNA) the phylogeographical patterning of clonal lineages to ascertain historical biogeographical structuring across this region. Our results will be compared with previous work on this arctic species complex (Weider et al., 1987; Dufresne \& Hebert, 1994, 1995; Weider \& Hobæk, 1994; Weider et al., 1996). At least four 'taxa', D. pulex, D. pulicaria, $D$. middendorffiana, and $D$. tenebrosa, have been recognized in the arctic Daphnia pulex complex (Hebert, 1995), with strong evidence of interspecific hybridization within this complex. Recent mtDNA sequencing data (J. K. Colbourne, L. J. Weider, T. J. Crease, F. Dufresne, A. Hobæk \& P. D. N. Hebert, unpublished data) indicate the presence of two major clades (termed 'pulex triad' and 'tenebrosa') in this circumarctic complex.

\section{Materials and methods}

The study area (Fig. 1, Table 1) ranged from western Russia (Kola Peninsula and Karelia) to the eastern fringe of Siberia, and included collections from several offshore islands, most notably the New Siberian Islands and Wrangel Island, a well-known Pleistocene glacial refuge (Vartanyan et al., 1993). Animals were collected by wading through each tundra pond/rockpool with a hand-held plankton net $(250 \mu \mathrm{m})$; no attempt was made to quantify population densities. Animals were sorted in the field and
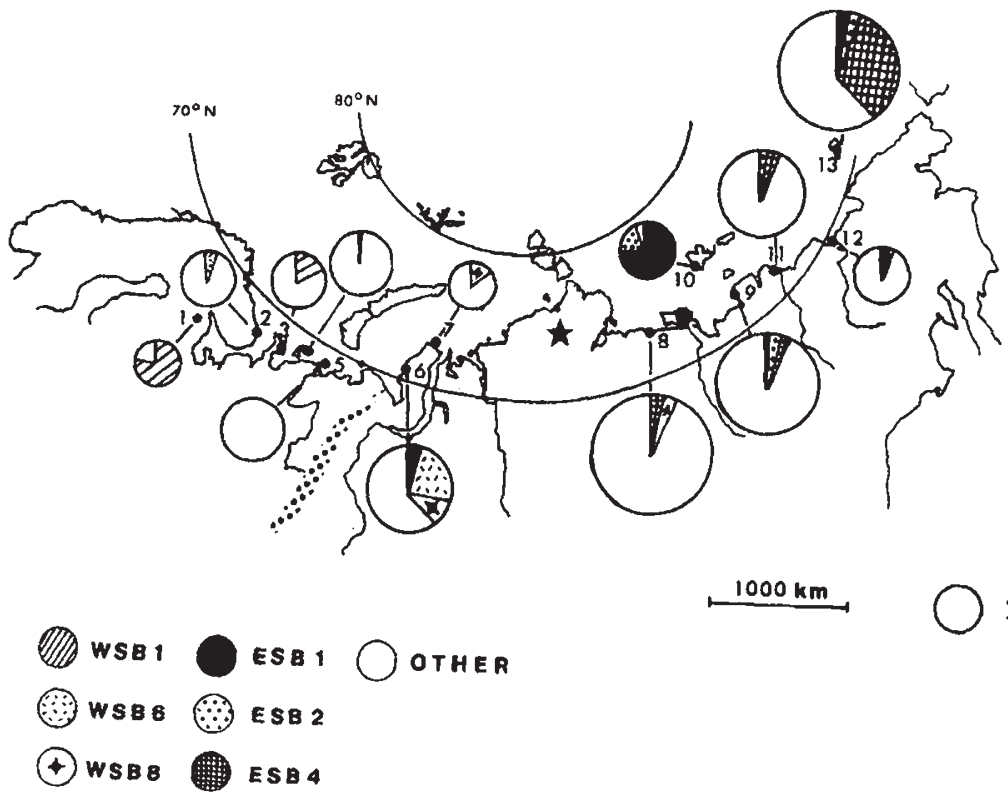

Fig. 1 Map showing the locations of the 13 sampling sites for the Daphnia pulex complex (see Table 1 for site designations and latitude and longitude coordinates). The black star indicates the location of the Taimyr Peninsula, and the dotted area indicates the location of the Ural Mountains. The distributions of six of the most abundant and widespread allozyme clones (see Table 3) are shown. Pie diagrams show the frequencies of the various clones at each site. The size of each circle is directly proportional to the haplotype diversity at a given site (a value of 2.0 haplotypes per site is shown for comparative purposes). 
Table 1 Summary of the number of populations surveyed and total sample sizes ( $N=$ number of animals sampled) for each regional survey (site designations correspond to Fig. 1)

\begin{tabular}{|c|c|c|c|c|c|c|c|c|c|}
\hline Region & Site no. & Lat. & Long. & $\begin{array}{l}\text { No. of } \\
\text { ponds }\end{array}$ & $\begin{array}{l}\text { No. of } \\
\text { clones }\end{array}$ & $N$ & $\begin{array}{l}\text { Clonal } \\
\text { richness }\end{array}$ & $\begin{array}{l}\text { Clonal } \\
\text { diversity }\end{array}$ & $\begin{array}{l}\text { Regional } \\
\text { diversity }\end{array}$ \\
\hline \multicolumn{10}{|c|}{ Western Russia/Sib. (WSB) } \\
\hline $\begin{array}{l}\text { Karelia } \\
\text { (WSB-1) }\end{array}$ & 1 & $64-70^{\circ} \mathrm{N}$ & $33-35^{\circ} \mathrm{E}$ & 23 & 6 & 883 & $117(0.10)$ & $105(0.04)$ & 0007 \\
\hline $\begin{array}{l}\text { Kachkovsky Bay } \\
\text { (WSB-2) }\end{array}$ & 2 & $67^{\circ} 12^{\prime} \mathrm{N}$ & $41^{\circ} 17^{\prime} \mathrm{F}$ & 5 & 22 & 149 & $480(238)$ & $368(179)$ & 0148 \\
\hline $\begin{array}{l}\text { Kanin Penin. } \\
\text { (WSB-3) }\end{array}$ & 3 & $68^{\circ} 20^{\prime} \mathrm{N}$ & $45^{\circ} 54^{\prime} \mathrm{E}$ & 6 & 15 & 160 & $3.83(0.39)$ & $1.96(0.29)$ & 0.094 \\
\hline $\begin{array}{l}\text { Kolguyev Isle } \\
\text { (WSB-4) }\end{array}$ & 4 & $68^{\circ} 44^{\prime} \mathrm{N}$ & $48^{\circ} 42^{\prime} \mathrm{E}$ & 9 & 24 & 269 & $3.56(0.33)$ & $2.30(0.15)$ & 0.089 \\
\hline $\begin{array}{l}\text { Pechora Bay } \\
\text { (WSB-5) }\end{array}$ & 5 & $68^{\circ} 53^{\prime} \mathrm{N}$ & $53^{\circ} 34^{\prime} \mathrm{E}$ & 8 & 37 & 239 & $5.30(0.70)$ & $2.84(0.39)$ & 0.155 \\
\hline $\begin{array}{l}\text { W.Yamal Penin. } \\
\text { (WSB-6) }\end{array}$ & 6 & $70^{\circ} 11^{\prime} \mathrm{N}$ & $67^{\circ} 17^{\prime} \mathrm{E}$ & 12 & 42 & 248 & $5.18(0.76)$ & $2.85(0.48)$ & 0.169 \\
\hline $\begin{array}{l}\text { Belyi Isle } \\
\text { (WSB-7) }\end{array}$ & 7 & $73^{\circ} 05^{\prime} \mathrm{N}$ & $70^{\circ} 07^{\prime} \mathrm{E}$ & 8 & 8 & 240 & $1.89(0.14)$ & $1.24(0.05)$ & 0.033 \\
\hline $\begin{array}{l}\text { Eastern Russia/Sib } \\
\text { Olenekskyi }\end{array}$ & & & & & & & & & \\
\hline (ESB-1) & 8 & $72^{\circ} 59^{\prime} \mathrm{N}$ & $120^{\circ} 33^{\prime} \mathrm{E}$ & 19 & 45 & 501 & $4.76(0.56)$ & $2.53(0.41)$ & 0.090 \\
\hline $\begin{array}{l}\text { Shirokostan } \\
\text { (ESB-2) }\end{array}$ & 9 & $72^{\circ} 24^{\prime} \mathrm{N}$ & $139^{\circ} 33^{\prime} \mathrm{E}$ & 18 & 83 & 507 & $5.59(0.94)$ & $2.80(0.43)$ & 0.164 \\
\hline $\begin{array}{l}\text { Kotelnyi Isle } \\
\text { (ESB-3) }\end{array}$ & 10 & $75^{\circ} 01^{\prime} \mathrm{N}$ & $137^{\circ} 45^{\prime} \mathrm{E}$ & 18 & 6 & 540 & $1.67(0.19)$ & $1.26(0.09)$ & 0.011 \\
\hline $\begin{array}{l}\text { NW Indigirka } \\
(\mathrm{ESB}-4)\end{array}$ & 11 & $71^{\circ} 36^{\prime} \mathrm{N}$ & $149^{\circ} 15^{\prime} \mathrm{E}$ & 21 & 84 & 633 & $5.90(0.92)$ & $3.14(0.53)$ & 0.133 \\
\hline $\begin{array}{l}\text { Kolyma Delta } \\
\text { (ESB-5) }\end{array}$ & 12 & $69^{\circ} 32^{\prime} \mathrm{N}$ & $160^{\circ} 44^{\prime} \mathrm{E}$ & 14 & 58 & 382 & $4.14(0.58)$ & $4.29(1.71)$ & 0.152 \\
\hline $\begin{array}{l}\text { Wrangel Isle } \\
\text { (ESB-6) }\end{array}$ & 13 & $70^{\circ} 58^{\prime} \mathrm{N}$ & $179^{\circ} 34^{\prime} \mathrm{E}$ & 6 & 65 & 180 & $11.30(3.73)$ & $8.3 .0(2.81)$ & 0.361 \\
\hline Total & & & & 167 & 495 & 4931 & $4.55(0.73)$ & $2.94(0.54)$ & 0.124 \\
\hline
\end{tabular}

Mean clonal richness ( $\pm 1 \mathrm{SE})$, mean clonal diversity $( \pm 1 \mathrm{SE})$, and regional diversity were calculated as described in the text.

frozen in liquid nitrogen for later allozymic and DNA analyses.

\section{Allozyme electrophoresis}

Individual Daphnia were analysed electrophoretically using cellulose acetate electrophoresis (Hebert \& Beaton, 1989). Eight loci were screened routinely: Ao (aldehyde oxidase, EC 1.2.3.1); Apk (arginine phosphokinase, EC 2.7.3.3); Fum (fumarate hydratase, EC 4.2.1.2); Got (glutamic-oxaloacetic transaminase, EC 2.6.1.1); $L d h$ (lactate dehydrogenase, EC 1.1.1.27); Mpi (mannose-6-phosphate isomerase, EC 5.3.1.8); Pgm (phosphoglucomutase, EC 5.4.2.2) and $P g i$ (phosphoglucoisomerase, EC 5.3.1.9). Generally, we screened 30-40 individuals per population for the eight enzyme loci.

(c) The Genetical Society of Great Britain, Heredity, 78, 363-372.
Allelic arrays were inferred from the different electromorph patterns, based on the known quaternary structure of each enzyme. Multilocus composite genotypes were designated based on the composite electromorph patterns from the eight loci. In the remainder of this paper, we will use the term composite genotype and clone synonymously, although we are well aware that unassessed genetic variation undoubtedly exists within each clone (clones should be viewed as clonal groups). Therefore, our estimates of clonal richness and diversity should be viewed as conservative estimates.

Clonal richness was calculated as the number of unique eight-locus genotypes per population, whereas clonal diversity, defined as the effective number of clones per population, was calculated as $1 / C$ (Simpson's measure of concentration $C=\Sigma p_{i}^{2}$, 
where $p_{i}$ is the frequency of the $i$ th clone in a population, and the summation is over all clones; Parker, 1979). Clonal richness and clonal diversity were calculated for each population. Further, we calculated regional mean values for clonal richness by dividing the number of unique eight-locus genotypes per region by the total number of animals analysed from that region. Again, our clonal richness and diversity estimates should be viewed rather conservatively, given that previous studies (Hebert $e t$ $a l ., 1988)$ have shown that sampling effort and clonal detection do not follow a simple linear relationship.

\section{mtDNA analyses}

After having screened populations for allozymic variation, we then chose representative populations from each region to be analysed for mitochondrial $(\mathrm{mt})$ DNA variability. Frozen individuals were dissected so that the head portion was screened for diagnostic allozyme loci to determine allozyme clone designation, whereas the remainder of the tissue was used in the mtDNA analysis. Total genomic DNA was extracted from this tissue using the Isoquick Kit (MicroProbe, Garden Grove, CA). The polymerase chain reaction (PCR) was used to amplify a 2100 base-pair (bp) fragment of the NADH-4 and NADH-5 subunits of the mtDNA molecule following the methods of Weider et al. (1996).

Amplified PCR products were then subjected to endonuclease digestion following the manufacturer's recommendations (New England Biolabs) using six four-base cutters: DpnII, HaeIII, HhaI, MspI, Sau96I, and TaqI. Composite mtDNA haplotypes were designated based on the digestion profiles from the six endonucleases. Digestion profiles for each enzyme were labelled alphabetically starting with the letter $A$. Digested products were electrophoresed, stained, and photographed as outlined in Weider et al. (1996). (Restriction fragment pattern profiles for each restriction enzyme, as well as composite haplotype designations for all haplotypes are available from the authors by request.) Further, mtDNA haplotype diversity at each site was calculated as the effective number of haplotypes per site, using Simpson's measure of concentration as previously described for the allozyme clonal analysis.

Fragment sizes were assessed visually, and restriction sites were inferred and analysed using the REAP computer program (McElroy et al., 1991) to generate a complete data set showing the presence/ absence of sites observed for each unique haplotype. These data were then used to calculate sequence divergence between all pairs of haplotypes using the method of Nei \& Tajima (1983). The NElGHBor program of PHyLIP (Felsenstein, 1993) was used to cluster the mtDNA haplotypes based on their genetic distances using the neighbour-joining algorithm. The JUMBLE-option was used to randomize the order of input of haplotypes into the analysis. Ten runs of the program (using an a priori divergent haplotype, 72-W, as the outgroup) did not alter appreciably the topology of the resulting neighbourjoining tree.

Spatial distributions of haplotypes were analysed using the AIDA spatial autocorrelation program of Bertorelle \& Barbujani (1995) to determine whether any significant geographical patterning of haplotypes was present. The AIDA program measures whether, and to what extent, individual haplotypes resemble haplotypes sampled at arbitrarily chosen spatial distances. The resulting correlogram allows one to examine the spatial patterning of haplotypes and to infer potential mechanisms (selection, migration) influencing haplotype distributions. One thousand random permutations of the data set were conducted.

Genetic distance matrices were calculated based on 106 isolates that represented major and minor clonal lineages, from which we had both allozyme and mtDNA data. A Mantel test using the matrix comparison program MXCOMP of NTSYS-pc (Rohlf, 1990) was used to determine the degree of association between the two genetic distance matrices.

\section{Results}

\section{Allozymes}

Six alleles were detected at $M p i$ and $P g i$, whereas five alleles each were found at $A o$ and $P g m$, and four alleles each at Apk, Fum, Got and Ldh (Table 2). Generally, allelic arrays did not vary considerably across the survey area, although certain private alleles (allele 4 at $P g m$ and allele 0 at Got at site WSB-5) were found at certain sites, and the distribution of rare alleles was generally restricted to neighbouring sites (allele 0 at $L d h$ was detected only at sites ESB-8 and ESB-9).

A total of 167 ponds were sampled during the survey, and 474 unique eight-locus genotypes (clones) were detected. A total of 21 clones were found at multiple sites, with 13 of these clones constituting 46.2 per cent of the total number of animals sampled (Table 3). Clonal richness and clonal diversity estimates (Table 1) ranged from $1.17-11.30$ and 1.05-8.30, respectively, whereas regional (clonal) diversity varied from $0.007-0.361$. A comparison of clonal diversity values between 
western Russian/Siberian (WSB) sites, which were glaciated during most of the Pleistocene and eastern Russian/Siberian (ESB, i.e. Beringian) sites, which were unglaciated, indicated higher mean ( $\pm 1 \mathrm{SE})$ values for ESB sites $(3.72 \pm 1.09)$ when compared with WSB sites $(2.27 \pm 0.38)$. These mean values were marginally nonsignificant at the $P=0.10$ level (Wilcoxon two-sample test, $U_{7,6}=30$ ).

We observed that four of the six populations collected at site 13 (Wrangel Island, Fig. 1)

Table 2 Presence/absence of alleles for each of the eight polymorphic loci at each of the sites

\begin{tabular}{ccccccccc}
\hline & \multicolumn{7}{c}{ Locus } \\
\cline { 2 - 9 } Site & $P g m$ & $P g i$ & Ao & Got & Ldh & Mpi & Fum & Apk \\
\hline WSB & & & & & & & & \\
1 & 1,2 & 1,4 & $0,1,2$ & 2,3 & 1,3 & 3,4 & 3 & 3 \\
2 & $0,1,2,3$ & $0,1,4,5,6$ & $0,1,2,3$ & 2,3 & $1,3,4$ & $1,3,4,5,6$ & 3,4 & 3,4 \\
3 & $0,1,2,3$ & $0,1,4,5$ & $0,1,2,3$ & $1,2,3$ & 1,3 & $1,3,4,5,6$ & $2,3,4$ & $2,3,4$ \\
4 & $0,1,2,3$ & $0,1,4,5$ & $-1,0,1,2$ & $1,2,3$ & 1,3 & $1,2,3,4,5,6$ & $2,3,4$ & $3,4,5$ \\
5 & $0,1,2,3,4$ & $1,4,5$ & $-1,0,1,2,3$ & $0,2,3$ & $1,3,4$ & $3,4,5,6$ & 3,4 & 3,4 \\
6 & $0,1,2,3$ & $0,1,4,5$ & $-1,0,1,2,3$ & $1,2,3$ & 1,3 & $1,3,4,5,6$ & 3,4 & $2,3,4$ \\
7 & $1,2,3$ & $0,1,4,5$ & $0,1,2$ & 2 & 1,3 & $3,4,5$ & 3,4 & 3,4 \\
ESB & & & & & & & & \\
8 & $0,1,2,3$ & $0,1,4,5,6$ & $-1,0,1,2$ & 2,3 & 0,1 & $1,2,3,4$ & $2,3,4$ & 3,4 \\
9 & $0,1,2,3$ & $0,1,4,5,6,7$ & $-1,0,1,2,3$ & $1,2,3$ & $0,1,3$ & $1,2,3,4,5,6$ & $1,2,3,4$ & $2,3,4$ \\
10 & 2 & $1,4,5$ & 1,2 & 2 & 1 & $1,3,4,5$ & 3 & 3,4 \\
11 & $0,1,2,3$ & $0,1,4,5,7$ & $-1,0,1,2$ & $1,2,3$ & 1,3 & $1,2,3,4,5,6$ & $2,3,4$ & $3,4,5$ \\
12 & $0,1,2$ & $0,1,4,5$ & $-1,0,1,2$ & 2,3 & 1 & $1,2,3,4$ & 2,3 & $2,3,4$ \\
13 & $1,2,3$ & $0,1,4,5$ & $0,1,2,3$ & 2,3 & 1 & $1,2,3,4,5$ & $2,3,4$ & 4 \\
\hline
\end{tabular}

Site designations follow those given in Table 1.

WSB, western Russia/Siberia; ESB, eastern Russia/Siberia.

Alleles depicted in italic were detected at frequencies greater than 10 per cent.

Allelic frequencies are available from the authors upon request.

Table 3 Most common composite genotypes for clones in the arctic Daphnia pulex s.l. complex based on the electromorph patterns at the eight polymorphic enzyme loci (loci are described in the Methods section)

\begin{tabular}{lcccccccc}
\hline Clone & Pgm & Pgi & Ao & Got & Ldh & Mpi & Fum & Apk \\
\hline WSB-1 (0.147) & 22 & 11 & 00 & 22 & 11 & 44 & 33 & 33 \\
WSB-2 (0.035) & $23^{*}$ & 01 & 22 & 22 & 33 & 44 & 34 & 44 \\
WSB-3 (0.024) & 12 & 14 & 12 & 23 & 11 & 33 & 33 & 33 \\
WSB-4 (0.014) & $02^{*} 3$ & 15 & 12 & 12 & 33 & $5^{*} 6$ & 33 & 34 \\
WSB-5 (0.013) & 12 & 14 & 12 & 23 & 13 & 33 & 33 & 33 \\
WSB-6 (0.012) & $12^{*}$ & 44 & 11 & 23 & 33 & $5^{*} 6$ & 33 & 34 \\
WSB-7 (0.011) & $12^{*}$ & 46 & 02 & 22 & 11 & $3^{* 4}$ & $3^{*} 4$ & $3^{*} 4$ \\
WSB-8 (0.010) & 22 & 44 & 00 & 22 & 11 & $3^{*} 4$ & 33 & $34^{*}$ \\
ESB-1 (0.085) & 22 & 45 & 11 & 22 & 11 & 13 & 33 & $34^{*}$ \\
ESB-2 (0.032) & 22 & 14 & 11 & 22 & 11 & 33 & 33 & 33 \\
ESB-3 (0.029) & 22 & 11 & 01 & 22 & 01 & 13 & 34 & 33 \\
ESB-4 (0.028) & 22 & 14 & 01 & 23 & 11 & 13 & 33 & 33 \\
ESB-5 (0.022) & 22 & 04 & -10 & 22 & 11 & $12^{*}$ & 33 & 33 \\
\hline
\end{tabular}

Allelic designations represent relative mobility classes (the lower the number, the smaller the anodal migration distance from the origin).

Clonal frequencies are given in parentheses and are based on a total sample size of $N=4931$.

${ }^{*}$ Refers to multiple copies of the allele preceding the symbol. 
contained males, and these populations had clonal richness values ranging from 12 to 21 clones (sample size of 30 animals per population). Three of these four populations did not deviate from H.W. expected genotype frequencies at several polymorphic loci $(A o, M p i$ and $P g i)$, thus indicating that sexual reproduction is probably occurring, at least within certain populations. Two additional populations (one population from site 9 had 27 clones out of 30 animals surveyed, and another population from site 12 had 17 clones out of a sample size of 30) also did not deviate from H.W. expectations, again indicating that sporadic sexual reproduction may be occurring.

Of the 13 most abundant clones, several clones were extremely widespread (Fig. 1), in the order of thousands of kilometres. For example, clone ESB-1 appears to have a centre of concentration at site 10 (Fig. 1), Kotelnyi Island, part of the New Siberian island archipelago, but it was also detected at much lower frequencies at sites 4, 6, 9, 12 and 13, an area spanning nearly the breadth of Russia/Siberia. Additional clones such as ESB-4, WSB-1 and WSB-6 show somewhat more restricted distributions, but were nonetheless detected at multiple sites separated by hundreds to thousands of kilometres. Clonal arrays were characterized by a few widespread clones at a given site, but with most clones ( $\approx 87$ per cent, 431 out of 495 clonal distributions) being restricted to single ponds. This indicates that the population genetic (clonal) structure in this arctic complex is extremely fragmented, with somewhat limited gene flow present. Further, a significant relationship between similarity in clonal arrays (based on Jaccard's index, Pielou, 1984) and geographical distance was determined for the major allozyme clones found across Russia/Siberia (Mantel $Z=-0.453, t=3.872,250$ random permutations, $P<0.004)$. Again, populations that were geographically more distant from each other also harboured more differentiated clonal arrays than those populations that were located near each other.

\section{$m t D N A$}

Results from the RFLP analysis indicated that 73 distinct mtDNA haplotypes were detected from 71 populations (total number of individuals $=247$ ) scattered across the survey area (Table 4). Most haplotypes (59 out of $73,80.8$ per cent) were restricted to single populations, but 11 haplotypes were detected at more than one site (Table 4). For example, haplotypes 1 and 2 (Table 4) were extremely widespread across the entire breadth of northern Russia/Siberia, whereas a number of more locally distributed haplotypes were restricted to sites east (haplotypes 3,19, 23, 24 and 40) and west (haplotypes 4, 8 and 11) of the Ural Mountains, respectively (Table 4). Haplotype diversity (on a regional basis) was highest at sites 8 and 13 (in Beringia, Fig. 1), with attentuation of diversity west of the Ural Mountains. The mean regional haplotype diversity $( \pm 1 \mathrm{SE}$ ) for unglaciated eastern Russian/Siberian sites (sites 8-13, Fig. 1, Hopkins et al., 1982) was $6.23 \pm 1.17$ haplotypes per site, whereas the mean ( $\pm 1 \mathrm{SE})$ haplotype diversity for glaciated western Russian/Siberian sites (sites $1-7$, Fig. 1) was $4.00 \pm 0.63$ haplotypes per site. The difference between these mean values was marginally nonsignificant (critical probability $P=0.10-$ 0.05 , Wilcoxon two-sample test, $U_{7,2}=32$ ).

Results from the spatial autocorrelation analysis (Fig. 2) revealed significant positive spatial autocorrelation for distance classes 1,2 and 3 (distance classes with boundaries of $0-1000 \mathrm{~km}, 1000$ $2000 \mathrm{~km}$ and $2000-3000 \mathrm{~km}$ ), whereas significant negative autocorrelation was detected for the three most distantly spaced classes (distance classes $3000-4000 \mathrm{~km}, 4000-5000 \mathrm{~km}$ and $>5000 \mathrm{~km}$ ). The shape of the autocorrelation function approximates a clinal pattern in the similarity of mtDNA haplotypes across the breadth of northern Russia/Siberia (Fig. 2), which may reflect both stochastic (limited gene flow, founder effect) and deterministic (selection) mechanisms.

Results from the neighbour-joining analysis of the mtDNA data set (Fig. 3) revealed clustering of lineages found in close proximity to each other (either found in the same population or a nearby population) for most of the minor (less widespread) haplotypes. Two major clades were observed: clade A (Fig. 3) corresponds to the tenebrosa clade (J. K. Colbourne, L. J. Weider, T. J. Crease, F. Dufresne, A. Hobæk \& P. D. N. Hebert, unpublished data), whereas clade B consists of divergent haplotypes 8 , 27, 39, 72 and 73 , that were isolated from sites 1-3 in western Russia (Fig. 1). Unpublished mtDNA sequencing data (J. K. Colbourne, L. J. Weider, T. J. Crease, F. Dufresne, A. Hobæk \& P. D. N. Hebert, unpublished data; L. J. Weider, A. Hobæk, P. D. N. Hebert, T. J. Crease \& J. K. Colbourne, unpublished data) indicate that these lineages are members of the 'pulex triad' clade.

The Mantel test revealed a nonsignificant association between genetic similarity based on the allozyme data set, and that based on the mtDNA RFLP analysis $(Z=-0.021, t=0.374,250$ random permutations, $P=0.35$ ).

(c) The Genetical Society of Great Britain, Heredity, 78, 363-372. 
Table 4 Distributions of the most widespread mtDNA haplotypes in the arctic Daphnia pulex s.l. complex across northern Russia/Siberia

\begin{tabular}{|c|c|c|c|c|c|c|c|c|c|c|c|c|c|}
\hline \multirow[b]{3}{*}{$\begin{array}{l}N= \\
\text { Haplotype }\end{array}$} & \multicolumn{13}{|c|}{ Site } \\
\hline & \multicolumn{7}{|c|}{ WSB } & \multicolumn{6}{|c|}{ ESB } \\
\hline & $\begin{array}{c}1 \\
12\end{array}$ & $\begin{array}{c}2 \\
17\end{array}$ & $\begin{array}{c}3 \\
23\end{array}$ & $\begin{array}{c}4 \\
19\end{array}$ & $\begin{array}{c}5 \\
11\end{array}$ & $\begin{array}{c}6 \\
24\end{array}$ & $\begin{array}{c}7 \\
12\end{array}$ & $\begin{array}{c}8 \\
22\end{array}$ & $\begin{array}{c}9 \\
23\end{array}$ & $\begin{array}{l}10 \\
12\end{array}$ & $\begin{array}{l}11 \\
18\end{array}$ & $\begin{array}{l}12 \\
14\end{array}$ & $\begin{array}{l}13 \\
40\end{array}$ \\
\hline 1 & & 0.118 & 0.174 & 0.368 & & 0.292 & & & 0.043 & & 0.056 & 0.357 & \\
\hline $\begin{array}{l}\text { BGXAAH } \\
2\end{array}$ & & & $\begin{array}{l}(4,2) \\
0.105\end{array}$ & & & & 0.667 & & $\begin{array}{l}(1,1) \\
0.261\end{array}$ & 0.500 & & & 0.025 \\
\hline $\begin{array}{l}\text { ВАПАAП } \\
3\end{array}$ & & & & & & & & 0.136 & 0.174 & & 0.278 & & \\
\hline $\begin{array}{l}\text { BGXAJH } \\
4\end{array}$ & & 0.059 & 0.435 & 0.105 & & 0.125 & & $(3,1)$ & $(4,1)$ & & $(5,1)$ & & \\
\hline $\begin{array}{l}\text { BGYAAH } \\
8 \\
\text { GFDADC }\end{array}$ & $\begin{array}{l}0.667 \\
(8,8)\end{array}$ & $(1,1)$ & $\begin{array}{c}(10,3) \\
0.130 \\
(3,1)\end{array}$ & $(2,1)$ & & $(3,1)$ & & & & & & & \\
\hline $\begin{array}{l}11 \\
\text { KGcBAJ }\end{array}$ & & & & & $\begin{array}{c}0.273 \\
(3,1)\end{array}$ & & $\begin{array}{c}0.083 \\
(1,1)\end{array}$ & & & & & & \\
\hline $\begin{array}{l}19 \\
\text { BAhHAM }\end{array}$ & & & & & & & & $\begin{array}{l}0.045 \\
(1.1)\end{array}$ & & & & & $\begin{array}{l}0.150 \\
(6.1)\end{array}$ \\
\hline 23 & & & & & & & & 0.136 & & & 0.111 & & \\
\hline PAUAAH & & & & & & & & $(3,1)$ & & & $(2,1)$ & & \\
\hline 24 & & & & & & & & & & 0.250 & 0.167 & & 0.175 \\
\hline BAUAAH & & & & & & & & & & $(3,1)$ & $\begin{array}{l}(3,2) \\
0.111\end{array}$ & & $(7,1)$ \\
\hline $\begin{array}{l}31 \\
\text { BGWAAH }\end{array}$ & & & & & $\begin{array}{c}0.182 \\
(2,1)\end{array}$ & $\begin{array}{c}0.083 \\
(2,1)\end{array}$ & & $\begin{array}{l}0.182 \\
(4,2)\end{array}$ & $(1,1)$ & & $(2,1)$ & & \\
\hline $\begin{array}{l}\text { BGWAAH } \\
40\end{array}$ & & & & & & & & & & & 0.056 & & 0.025 \\
\hline BAtAAH & & & & & & & & & & & $(1,1)$ & & $(1,1)$ \\
\hline
\end{tabular}

Haplotypes are designated by a number, and then the corresponding six enzyme designations in the order DpnII, TaqI, HaeIII, HhaI, MspI and Sau96I. See Table 1 or Fig. 1 for site information. Haplotype frequencies at each site are given. Sample sizes for individual haplotypes followed by the no. of ponds in which a given haplotype was detected are given in parentheses. Total sample size for each site $(N)$ is listed under the corresponding site no. WSB, western Russia/Siberia; ESB, eastern Russia/Siberia. A total of 73 distinct haplotypes were detected, with 62 haplotypes restricted to single sites, and 59 of these 62 haplotypes restricted to single ponds $(59 / 73=80.8$ per cent restricted to single ponds).

\section{Discussion}

Results from this study support earlier work (Weider et al., 1987; Weider \& Hobæk 1994; Weider et al., 1996), which characterized the highly fragmented population genetic (clonal) structure of members of the arctic Daphnia pulex complex. This present paper represents the first attempt ever at assessing the population genetic and clonal structure of members of this arctic complex from Russia/ Siberia on either a micro- or macrogeographical scale. In addition, the highest recorded levels of clonal richness/diversity in this arctic complex were found in eastern Siberia, in the heart of the Beringian glacial refuge. As mentioned previously, these estimates of clonal richness and diversity should be viewed as conservative estimates; this complex consists most likely of thousands to perhaps tens of thousands of clones (L. J. Weider, A. Hobæk, P. D. N. Hebert, T. J. Crease \& J. K. Colbourne, unpublished data). Evidence of sporadic sexual reproduction in certain populations from Beringia indicates that this region could serve as a 'hot spot' of increased clonal diversity, which fuels the production of novel clones. Previous studies (Weider et al., 1987; Weider \& Hobæk, 1994) did not detect evidence of sporadic sexual reproduction occurring across vast expanses of the Arctic. However, recent evidence (L. J. Weider, A. Hobæk \& P. D. N. Hebert, personal observations), combined with earlier observations (Tash, 1971) have indicated that occasional sexual reproduction in this complex is occurring in western N.W.T. (an area near Tuktoyaktuk, on the eastern fringe of Beringia), and 


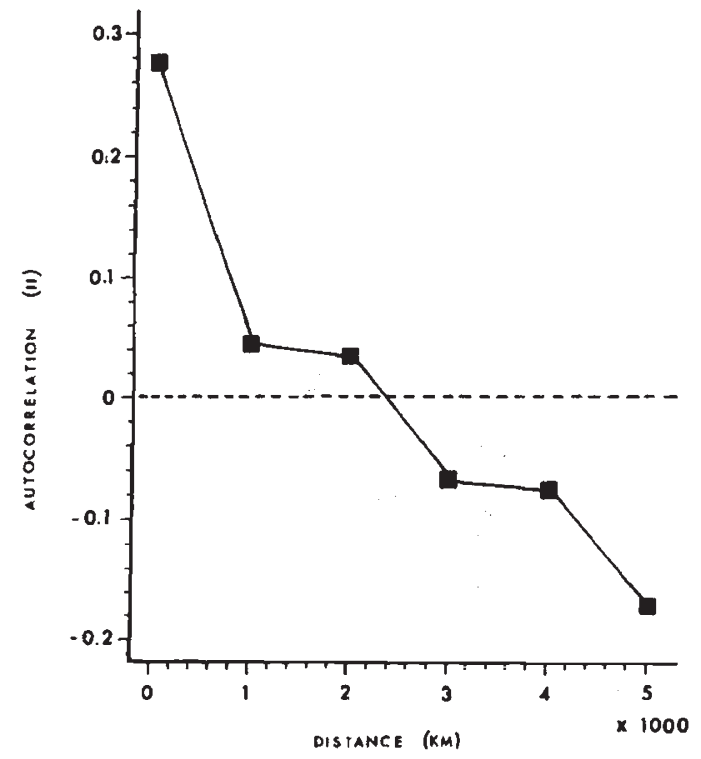

Fig. 2 Spatial correlogram depicting the autocorrelation coefficient (II) as a function of distance across the survey area for the mtDNA haplotype data set. Mean II values ( \pm 99 per cent confidence intervals) are depicted. The confidence intervals are smaller than the size of the blackened squares. Distance classes were chosen arbitrarily using the criterion equal width of distance class (Bertorelle \& Barbujani, 1995). Distance classes were: $0 \mathrm{~km}$, $1000 \mathrm{~km}, 2000 \mathrm{~km}, 3000 \mathrm{~km}, 4000 \mathrm{~km}$ and $5000 \mathrm{~km}$.

NW Alaska. Together, these data suggest that Beringia is a centre of occurrence of sexual reproduction in this arctic complex (primarily in the tenebrosa clade, L. J. Weider \& P. D. N. Hebert, unpublished data) and sex may be more widespread in the arctic D. pulex complex than was previously believed.

The spatial analyses revealed significant spatial structuring of the distribution both of allozyme clones and mtDNA haplotypes. The widespread distribution of certain clones/haplotypes (haplotypes 1, 2 and 31, Table 4) suggests that these haplotypes represent either more ancient lineages, which have had a longer time to disperse from ancestral sites, or they represent highly vagile lineages. We are currently gathering mtDNA sequencing data (J. K. Colbourne, L. J. Weider, T. J. Crease, F. Dufresne, A. Hobæk \& P. D. N. Hebert, unpublished data; L. J. Weider, A. Hobæk, P. D. N. Hebert, T. J. Crease \& J. K. Colbourne, unpublished data), which should allow us to make phylogenetic inferences concerning the relative ages of the haplotypes. Further, sample sizes were too small to make any definitive state. ments about potential centres of origin for many of the clones. However, one might conclude from both the allozyme and mtDNA data sets (Tables 3 and 4, Fig. 1), that because the highest levels of clonal/

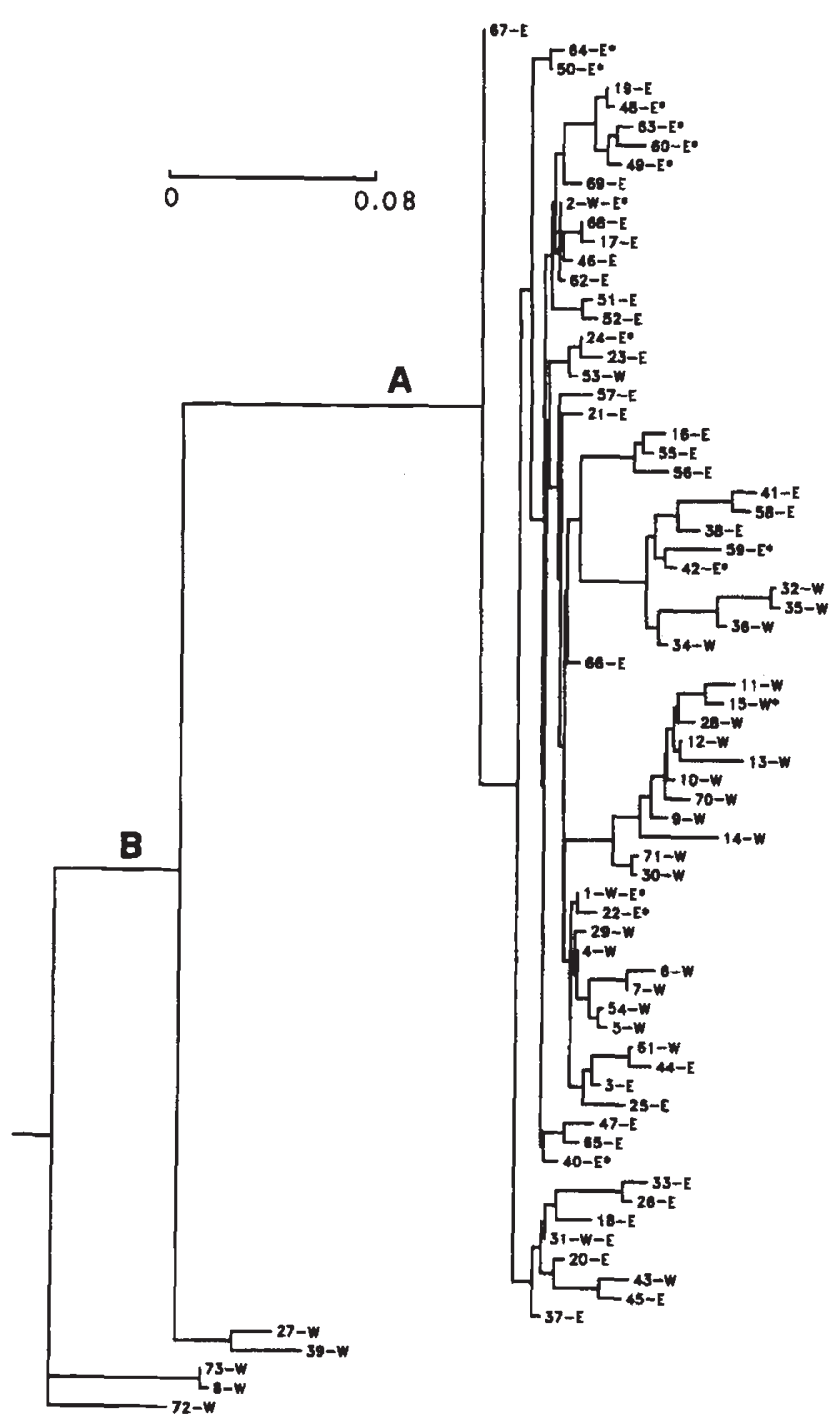

Fig. 3 Neighbour-joining tree generated from the genetic distance matrix based on the restriction site variation in isolates of the Daphnia pulex complex from across Russia/ Siberia. Each isolate is designated by its haplotype number, followed by either E (eastern Russian/Siberian sites, Table 1) or W (western Russian/Siberian sites), or both. Haplotypes having melanic isolates are indicated by asterisks. Scale bar is given. Clade A represents tenebrosa lineages, whereas clade B represents the 'pulex triad' clade (J. K. Colbourne, L. J. Weider, T. J. Crease, F. Dufresne, A. Hobæk \& P. D. N. Hebert, unpublished data). The tree was rooted using haplotype $72-W$ as the outgroup. (Ten runs of the program using the JUMBLE option indicated that the topology of the tree was not greatly affected by the input order of haplotypes.)

haplotype richness (diversity) were found in eastern Russia/Siberia, along with a number of widespread lineages, this region has most probably served as a source for many of the clonal lineages that have subsequently recolonized the glaciated portions of 
Russia/Siberia; i.e. sites west of the Ural Mountains (Fig. 1). Interestingly, the most divergent mtDNA lineages (haplotypes $8,27,39,72$ and 73 , representing the 'pulex triad' clade, Fig. 3) were found only in western Russia (sites 1-3, Table 1, Fig. 1). These data suggest that postglacial colonization of this region occurred via migrants from a glacial refuge other than Beringia. Further sampling in central and southern Europe might help to elucidate the region of origin of these haplotypes.

Mantel test results indicated no significant association between the allozyme and mtDNA genetic distance matrices. Van Raay \& Crease (1995) have argued that such a lack of association between the nuclear and mitochondrial genomes is indicative of interspecific hybridization, an observation that they noted for populations of the $D$. pulex complex found in arctic Canada. We believe that the high levels of heterozygosity, as shown for the 13 most abundant clones (Table 3; mean heterozygosity $\pm 1 \mathrm{SE}=0.432 \pm$ 0.063 , range $0.000-0.750$ ) and numerous other clones in this present study, argue strongly for multiple hybrid origins for many of these clones. In addition, the presence of 'unbalanced' heterozygous electromorphs indicates that many of these clones are undoubtedly polyploids, an observation that has been verified from arctic Canadian populations in this complex (Beaton \& Hebert, 1988).

\section{Biogeography and Beringia}

As noted in the introduction, Beringia has served as the major arctic glacial refuge during the Pleistocene (Hopkins et al., 1982). For both actively (large mammals) and passively (plants, small aquatic invertebrates) dispersed organisms, little is known about the extent of intraspecific genetic variation in populations inhabiting known glacial refuges (Sage \& Wolff, 1986). This present study represents one of the most comprehensive studies to date on the population genetic structure of a group of organisms, the D. pulex complex. Given the Holarctic distribution of members of this complex (Haney \& Buchanan, 1987), and the high levels of clonal/ haplotype diversity noted at sites in Beringia, we conclude that members of this complex have most probably inhabited vast expanses of Beringia throughout the Pleistocene.

Small aquatic invertebrates such as Daphnia rely on passive dispersal of resting stages (ephippia) by a number of potential vectors (including migratory waterfowl, wind, and water currents) in order to migrate between isolated ponds/lakes. Recent results (Alerstam et al., 1995) indicate that migratory water- fowl across our present study area could potentially play an important role in the dispersal of ephippia between habitats. Interestingly, Alerstam et al. (1995) determined that the Taimyr Peninsula (Fig. 1) appears to serve as a partial geographical barrier to migratory arctic birds. Through the use of sophisticated radar tracking of flocks, they observed that the migratory avian fauna west and east of the Taimyr Peninsula show distinctly different migration routes. The western Taimyr birds follow a transEuropean route, whereas eastern Taimyr birds follow either central Asian or Alaskan/North American flight paths. These observations suggest that if waterfowl play a role in the long-distance dispersal of Daphnia ephippia, then there may be reduced gene flow between regions west and east of the Taimyr Peninsula. Our results suggest that there are numerous clones/haplotypes (Table 4, Fig. 1) that are restricted to regions either east (ESB) or west (WSB) of the Taimyr. Interestingly, we were unable to detect the presence of members of this complex from several sites on the Taimyr (Hobæk, 1995). This could reflect the fact that because these sites were the most northerly sites sampled, climatic conditions may have been too harsh (a very short ice-free summer) for the Daphnia to complete ephippial egg production.

Arctic regions have been identified (Chapin \& Körner, 1994) as particularly sensitive biomes with respect to changes in biodiversity caused by anthropogenic changes in global climate (global warming, ozone depletion). Presently, little is known about levels of inter- and intraspecific bio(genetic) diversity across vast expanses of the Arctic, including the present study area. Results from our study are currently being incorporated into a circumarctic analysis of the phylogeography and ecological genetics of this species complex across its entire arctic range (L. J. Weider, A. Hobæk, P. D. N. Hebert, T. J. Crease \& J. K. Colbourne, unpublished data), which should afford us an unprecedented view of the population genetic (clonal) and phylogeographical structure in this complex. Further, our results should serve as a valuable model to compare with the phylogenetics and phylogeography of other important passively dispersed arctic organisms (e.g. Abbott et al., 1995).

\section{Acknowledgements}

We thank the following individuals and agencies for their help and support: Prof. Winfried Lampert, Director, Max-Planck-Institut für Limnologie, for his tremendous encouragement and support during the 
entire study; the crew of the Akademik Federov for logistical support; Eva Geißler and Ilka Senkpiehl provided their usual excellent technical assistance in the laboratory. Two anonymous reviewers provided helpful comments on an earlier version of the manuscript. The collecting trip to Siberia was funded through the Swedish Polar Research Council and the Russian Academy of Sciences - Tundra Ecology Expedition - 1994. Sampling in Karelia was made possible through the generous assistance of Prof. Vladimir Abakumov, Russian Academy of Sciences. Additional financial support was provided by the NATO Collaborative Research Grants Programme (Grant no. CRG910989), the Norwegian Research Council (Grant nos 105042/410 and 107177/720), and the Max-Planck-Gesellschaft.

\section{References}

ABBOTT, R. J., CHAPMAN, H. M., CRAWFORD, R. M. M. AND FORBES, D. G. 1995. Molecular diversity and derivations of populations of Silene acaulis and Saxifraga oppositifolia from the high arctic and more southerly latitudes. Mol. Ecol., 4, 199-207.

ALERSTAM, T., GUDMUNDSSON, G. A. AND LARSSON, B. 1995. Migration patterns and flight routes of tundra birds. In: Grönlund, E. and Melander, O. (eds) Swedish-Russian Tundra Ecology-Expedition-94: A Cruise Report, pp. 252-263. Swedish Polar Research Secretariat, Stockholm.

AVISE, J. C. 1994. Molecular Markers, Natural History, and Evolution. Chapman and Hall, New York.

BEATON, M. J. AND HEBERT, P. D. N. 1988. Geographical parthenogenesis and polyploidy in Daphnia pulex. Am. Nat., 132, 837-845.

BERNATCHEZ, L. AND DODSON, J. J. 1994. Phylogenetic relationships among palearctic and nearctic whitefish (Coregonus sp.) populations as revealed by mitochondrial DNA variation. Can. J. Fish. Aquat. Sci., 51, 240-251.

Bertorelle, G. AND Barbujanl, G. 1995. Analysis of DNA diversity by spatial autocorrelation. Genetics, 140, 811-819.

CHAPIN, F. S., III AND KÖRNER, C. 1994. Arctic and alpine biodiversity: patterns, causes, and ecosystem consequences. Trends Ecol. Evol., 9, 45-47.

DUFRESNE, F. AND HEBERT, P. D. N. 1994. Hybridization and the origins of polyploidy. Proc. R. Soc. B, 258, 141-146.

DUFRESNE, F. AND HEBERT, P. D. N. 1995. Polyploidy and clonal diversity in an arctic cladoceran. Heredity, $\mathbf{7 5}$, 45-53.

FELSENSTEIN, J. 1993. PHYLIP (Phylogeny Inference Package), version 3.5c. Department of Genetics, University of Washington, Seattle, WA.

HANEY, J. F. AND BUCHANAN, C. 1987. Distribution and biogeography of Daphnia in the arctic. Mem. Ist. Ital. Idrobiol. , 45, 77-105.

hebert, P. D. N. 1995. The Daphnia of North America: An
Illustrated Fauna. CD-ROM. Distributed by the author. Department of Zoology, University of Guelph, Ontario, Canada.

HEBERT, P. D. N. AND BEATON, M. J. 1989. Methodologies for Allozyme Analysis Using Cellulose Acetate Electrophoresis. A Practical Handbook. Helena Laboratories, Beaumont, TX.

HEBERT, P. D. N., WARD, R. D. AND WEIDER, L. J. 1988. Clonal-diversity patterns and breeding-system variation in Daphnia pulex, an asexual-sexual complex. Evolution, 42, 147-159.

НОВ£К, А. 1995. Ecological genetics of the Daphnia pulex complex - an arctic, circumpolar survey. In: Grönlund, E. and Melander, O. (eds) Swedish-Russian Tundra Ecology-Expedition-94: A Cruise Report, pp. 216-224. Swedish Polar Research Secretariat, Stockholm.

HOPKINS, D. M., MATTHEWS, J. V., JR, SCHWEGER, C. E. AND YOUNG, S. B. (eds) 1982. Paleoecology of Beringia. Academic Press, New York.

McElROY, D., MORAN, P., BERMINGHAM, E. AND KORNFIELD, 1. 1991. REAP - The Restriction Enzyme Analysis Package, version 4.0. University of Maine, Orono, ME.

NEI, M. AND TAJIMA, F. 1983. Maximum likelihood estimation of the number of nucleotide substitutions from restriction site data. Genetics, 105, 207-217.

PARKER, E. D., JR. 1979. Ecological implications of clonal diversity in parthenogenetic morphospecies. Am. Zool., 19, 753-762.

PIElou, E. C. 1979. Biogeography. John Wiley and Sons, New York.

PIElou, E. C. 1984. The Interpretation of Ecological Data: A Primer on Classification and Ordination. John Wiley and Sons, New York.

ROHLF, F. J. 1990. NTSYs-pc. Numerical Taxonomy and Multivariate Analysis System, version 1.6. Exeter Software, Setauket, NY.

SAGE, R. D. AND wOLFF, J. O. 1986. Pleistocene glaciations, fluctuating ranges, and low genetic variability in a large mammal (Ovis dalli). Evolution, 40, 1092-1095.

TASH, J. C. 1971. The zooplankton of fresh and brackish waters of the Cape Thompson area, northern Alaska. Hydrobiologia, 38, 93-121.

VAN RAAY, T. J. AND CREASE, T. J. 1995. Mitochondrial DNA diversity in an apomictic Daphnia complex from the Canadian high arctic. Mol. Ecol., 4, 149-161.

VARTANYAN, s. L., GARUTT, v. E. AND SHER, A. v. 1993. Holocene dwarf mammoths from Wrangel Island in the Siberian arctic. Nature, 362, 337-340.

WEIDER, L. J. AND HOBÆK, A. 1994. Molecular biogeography of clonal lineages in a high-arctic apomictic Daphnia complex. Mol. Ecol., 3, 497-506.

WEIDER, L. J., BEATON, M. J. AND HEBERT, P. D. N. 1987. Clonal diversity in high-arctic populations of Daphnia pulex, a polyploid apomictic complex. Evolution, 41, 1335-1346.

WEIDER, L. J., HOBÆK, A., CREASE, T. J. AND STIBOR, H. 1996. Molecular characterization of clonal population structure and biogeography of arctic apomictic Daphnia from Greenland and Iceland. Mol. Ecol., 5, 107-118. 